\title{
Nexus between Work Life Balance Practices and Employee Retention - The Mediating Effect of a Supportive Culture
}

\author{
Subhasree $\operatorname{Kar}^{1} \&$ K. C. Misra ${ }^{1}$ \\ ${ }^{1}$ Sambhram Academy of Management Studies, India \\ Correspondence: Subhasree Kar, Sambhram Academy of Management Studies, India. E-mail: \\ karsubhasree@yahoo.com
}

Received: April 9, 2013 Accepted: June 17, 2013 Online Published: August 30, 2013

doi:10.5539/ass.v9n11p63 URL: http://dx.doi.org/10.5539/ass.v9n11p63

\begin{abstract}
Today's competitive global environment and demanding workplace brings work life challenges for everyone all most in all sectors. The Indian IT industry characterized by long working hours, rigorous works, heavy work pressures and pressing deadlines always brings challenges for its employees. The employees are not willing to work in such organization where the prevailing culture is not supportive and many even quit the job; retention happens to be critical then. Off late it is the realization of most of the companies that if the work life conflicts of employees can be taken care of in an appropriate way then it can help in the retention of the talent. Companies interested in increasing organizational outcomes should enhance an organizational culture positive towards employees' balance, communicating their support towards work life balance initiatives.

The present study analyses the impact of work life balance practices on employee retention and the mediating effect of a supporting culture based on empirical evidence drawn from Indian IT sector. The findings show that a work life balance supportive culture mediates the effect of the availability of work life balance practices on organizational performance.
\end{abstract}

Keywords: mediating effect, supportive culture, retention, work life balance practices

\section{Introduction}

Life is a set of pursuits. No one can achieve a fulfilling and promising life without family, health, wealth, career, social obligations, intellectual satisfaction and spiritual enlightenment. To maintain the wheel of life moving, striking the balance is imperative. Work life balance means the harmonious and holistic integration of work and non-work so that people can achieve their potential across the domains in which they live.

The challenges of integrating work and family life is a part of everyday reality for majority of workforce. Employees work hard to strike a balance to fulfill the demands of the working life and meeting the commitments of family life. Those who fail to do so they either quit the organization thereby increasing the rate of attrition or become less productive. In the personal front also they feel unhappy. At this cross road organizational culture plays a crucial role to support the employees; high culture has a mediating effect to link the Work Life Policies and practices with talent retention.

\section{Significance of the Study}

Work -life balance in the present business context is of prime importance because of the nature of today's modern workforce characterized by higher rates of labour market participation by the women, a young workforce with generation ' $\mathrm{Y}$ ' employees, long working hours, work intensification, working in odd hours, emerging technology, global competitive market and our renewed interest in personal lives and family values.

\section{Literature Review}

Work Life Balance Practices are those institutionalized structural and procedural arrangements as well as formal and informal practices that enable individuals to easily manage the conflicting worlds of work and family leaves. (Osterman,1995) There is no one accepted definition of what constitutes a work-life balance practice, the term usually refers to one of the following: organizational support for dependent care, flexible work options, and family or personal leave (Estes \& Michael, 2005). Hence these practices include flexible work hours (e.g., flextime, which permits workers to vary their start and finish times provided a certain number of hours is worked; 
compressed work week, in which employees work a full week's worth of hours in four days and take the fifth off), working from home (telework), sharing a full-time job between two employees (job sharing), family leave programs (e.g., parental leave, adoption leave, compassionate leave), on-site childcare, and financial and/or informational assistance with childcare and eldercare services.

Work Life Balance Policies helps employee in managing their work and family in a better way and enhance their attitudes and behaviours such as organizational attachment (Groover and Croocker ,1995) ,Job Satisfaction (Kossek and Ozeki,1998) and intention to stay (Lobel and Kossek ,1996).

Today organizations are forced to look beyond the mundane human resources (HR) interventions and execute initiatives such as flexible working hours, alternative work arrangements, leave policies in lieu of family care responsibilities and employee assistant programs. These initiatives are refereed to as 'family friendly policies' or 'work-life balance 'practices in literature. (Grover and Crooker, 1995; Kopelman, Prottas, Thomson and Jahn, 2006).Most cited work family policies in work family literature are onsite day care, help with day care costs ,elder care assistant ,information on community day care ,paid parental leave, maternity and paternity leave with reemployment and flexible scheduling (Perry-Smith Et al ,2000). Employees who had access to family-friendly policies showed significantly greater organizational commitment and expressed significantly lower intention to quit their jobs (Grover \& Crooker, 1995). Where as the problem of work life balance is clearly linked with withdrawl behavior, including turnover and non-genuine sick absence (Hughes and Bozionelos, 2007).

Y. P. S. Kanwar, A. K. Singh and A. D. Kodwani (2009) in their study on the impact of work life balance and burnouts on job satisfaction in the context of IT and ITES industry revealed that work life balance and job satisfaction are positively related to each other and to increase the morale and productivity of the employees organizations should play a facilitating role to provide ways to manage work life balance.

Lourel, Michael T. Ford, Claire Edey Gamassou, Nicolas Gue'guen, Anne Hartmann (2008) in their research paper discussed about the importance of work life and home life and how home and work are related to perceived stress and job satisfaction.. They said that work-life is a crucial issue and employee commitment is particularly high in the organization that have work life balance policies and suggested that a workplace culture supportive of work-family balance, management support to employees is fundamental for employee commitment to the organization.

Ioanlazar, Codruta Osoian, Patriciaratiu (2010) in their research study said that availability and use of work-life balance practices, when provided in the context of supervisor and organizational support can reduce work-life conflict and increase positive appraisals of one's organization. These effects are often associated with employee attitudes such as increased job satisfaction, reduced absenteeism, and increased productivity, organizational commitment and loyalty with higher levels of organizational performance.

James A. Breaugh N. Kathleen Frye (2008) in their research paper examined the relation between the use of four family friendly employment practices (telecommuting, ability to take work home, flexible working hours and family leaves) and work - family conflict. The findings of the study suggested that employers that are concerned about work family conflict would be wise to offer family friendly practices (especially flexible working hours) and supervisors to support.

Vikas Shrotriya (2009) said that work life balance entails attaining equilibrium between professional work and other activities, so that it reduces friction between official and domestic/personal life and thus enhances efficiency and productivity of employees with increase in commitment and contentment.

Work-life programmes have the potential to significantly improve employee morale, reduce absenteeism and retain organizational knowledge, particularly during the difficult economic times. In today's global market place, as companies aim to reduce cost, it is necessary to understand the critical issue of work life balance and to champion work life programmes. Work life programmes offers a win-win situation for employers and employees (Lockwood, 2003; Landaur, 1997).

Rajanish Ratna (2008) in his article “Work Life Balance in IT Sector revealed that the work life of an employee has attracted a great concern because of a large number of problems related to employee health, monotony at workplace, declining levels of productivity and competence at the employee level .He has studied the work life programmes of Indian IT giants like TCS, Wipro, Tech Mahindra and discussed that work life balance diminishes as age increases and female employees require a flexi work environment and timings ,a healthy relationship with colleagues helps in maintain the balance. So organizations should provide provisions for development of one self, to support family needs, a flexible work culture with management support. 
Monalisa Bhattacharya Kaushik (2009) in a study on workplace Issues- "Exit interview", elaborated on a range of important strategies that are important to retain talent. He mentioned about the 1) freedom of the talented worker to work his work schedule 2) incentive packages 3) keeping and maintaining personal touch with the people 4) regular training sessions to help the employees achieve goals on their personalized career graphs 5) positive and constructive feedback on a regular basis 6) socialization of the employees to corporate culture. 7) Senior managers role as a committed leader and finally 8) the practice of fair treatment of all the employees so as to foster a positive work environment.

C. Janki (2009) in his article "Employee Retention" discussed that most challenging issue faced by today's global organization, is to retain their employees and provided insights into employee retention strategies, measures and techniques to minimize the rate of attrition. He said for retaining valuable employees the strategies of proper attention should be given to every employee, get the right people at right time, provide training and coaching plan for succession and acceleration pool, offer better career visibility, use explicit ranking systems tied to incentive and differentiate the organization with unique culture, can be adopted.

Baron and Hannan (2002) provide an instructive conceptual framework with three dimensions of employment blue prints for success in high- tech start-up firms. First a basis of attachment an retention includes compensation, quality of work and work group as a community; the social identity. This is a key basis for creating the second dimension for attachment Critesia for selection- which includes skills, exceptional talent/ potential and fit with a team or organization. Thirdly means of control and coordination include direct monitoring or peer or culture control, reliance on professional standards, and formal processes and procedures.

M. Sakthivel Murugan (2009) in his study inferred that organizational culture influencing performance among the employees in the IT industry depends on major factors such as organizational culture, work environment, safety and negotiation. It is concluded that all employees realized that a conducive organizational culture influence organizational performance in IT industry.

Organizational culture is also a deciding factor in employee retention. Brockbank (1999) notes that strategically proactive HR units create corporate cultures that support innovation and creativity. A culture that values interpersonal relationships and collaboration, a team orientation, and respect for people has been shown to result in longer tenure (Sheridan, 1992). Other retention drivers include a sense of connection between an employee's job and organization strategy and the organization's success, a reputation of integrity, and a culture of innovation (Corporate Leadership Council, 2004).

\section{Objectives of the Study}

The objective of the study is to

- Study the existing Work Life Balance Practices in the selected IT organizations in Bangalore.

- Analyze the impact of Work Life Balance Practices on Employee Retention.

- Find out the role of corporate culture in providing work life balance and thereby helping in retention of the employees.

\section{Hypothesis}

After conducting an extensive review of literature, the following hypothesis is developed in line with the research problem and objectives.

H1: There is significant positive relationship between the variables taken in the study that describes the supportive organizational culture and the factors of Work Life Balance Practices and Employee Retention.

\section{Scope of the Study}

The study is restricted to IT Industry. One hundred respondents of different ranks and file from six IT Organizations (Wipro, TCS, IBM, HCL, Infosys, Accenture) of Bangalore city have been taken for the study.

\section{Research Methodology}

1) Sample Size: 100

2) Sampling Method: A two stage sampling method with purposive sampling to choose the IT companies and Simple Random Sampling to choose the respondents were adopted.

\section{3) Data Source :}

a) Primary Data: The primary data was collected with the administration of a structured questionnaire in six IT companies of Bangalore. 
b) Secondary Data: Secondary data was collected with the help of various research journals, books, magazines, websites related to the field of study.

4) Data Analysis: The statistical tools like descriptive statistics, correlation, and regression are used with SPSS 20.0 version.

\section{Results and Discussions}

In today's demanding workplace how supportive work culture plays a great role to provide attractive work life balance practices and helps in employee retention was studied taking one hundred respondents from six IT organizations. Table 1 presents the demographic characteristics of the sample.

Table 1. Demographic profile of the respondents

\begin{tabular}{lll}
\hline Demographic Variables N=100 & & \\
\hline \multirow{2}{*}{ Gender } & Male & 70 \\
& Female & 30 \\
Age & Below 30 & 40 \\
\multirow{4}{*}{ Marital Status } & Above 30 & 60 \\
& Married & 76 \\
Spouse Working & Unmarried & 24 \\
& NA & 24 \\
& Working Spouse & 48 \\
Children & Not Working Spouse & 28 \\
& NA & 24 \\
Family with Dependents & Having Children & 51 \\
& No having Children & 25 \\
& No Dependent Family & 83 \\
\hline
\end{tabular}

The demographic distribution of 100 respondents on the basis of their age gender, marital status and working spouse, children and dependent parents were analyzed in the above table and it was observed that 40 per cent respondents were in the age group of below 30 years and 60 per cent were in the age group of above 30 years .Out of the total sample 30 per cent were female respondents and 70 per cent comprises the male respondents and among them 76 percent were married and 24 per cent were unmarried. From the 76 per cent married people 63 per cent have working spouse and 37 per cent are not working. From the 76 percent married people 67 per cent respondents having children. From the sample it was found that 83 per cent respondents have dependent family. Here the respondents profile present a varied workforce comprising a category of people who are young and newly started their professional career and another set of people who are in the middle age group and are every day sandwithched between their job responsibility and family priorities with children and aged parents.

In order to study the impact of work life balance on employee retention and the mediating role of the culture general relationship in these three variables were found by using correlation. The Table-2, below represents the mean, standard deviations and correlations of all variables involved in this research study. 
Table 2. Mean, $\mathrm{SD}$ and correlation $(\mathrm{N}=100)$

\begin{tabular}{|c|c|c|c|c|c|c|c|c|c|c|c|c|c|c|}
\hline Variables & Mean & SD & 1 & 2 & 3 & 4 & 5 & 6 & 7 & 8 & 9 & 10 & 11 & 12 \\
\hline $\begin{array}{l}\text { Corporate } \\
\text { Culture }\end{array}$ & 1.72 & $\begin{array}{l}1.08 \\
3\end{array}$ & 1 & & & & & & & & & & & \\
\hline $\begin{array}{l}\text { Supportive } \\
\text { Managemen } \\
t\end{array}$ & 2.26 & .691 & $\underset{* *}{.584}$ & 1 & & & & & & & & & & \\
\hline Flexi-timing & 1.75 & $\begin{array}{l}1.05 \\
8\end{array}$ & .644 & .491 & 1 & & & & & & & & & \\
\hline $\begin{array}{l}\text { Leave } \\
\text { Policy }\end{array}$ & 1.75 & $\begin{array}{l}1.03 \\
8\end{array}$ & .539 & .444 & .678 & 1 & & & & & & & & \\
\hline $\begin{array}{l}\text { Career } \\
\text { Break } \\
\text { Options }\end{array}$ & 1.87 & $\begin{array}{l}1.08 \\
9\end{array}$ & .723 & $\underset{* *}{.542}$ & $\underset{* *}{.708}$ & $\underset{* *}{.784}$ & 1 & & & & & & & \\
\hline $\begin{array}{l}\text { Employee } \\
\text { Assistant } \\
\text { Programs }\end{array}$ & 1.96 & $\begin{array}{l}1.21 \\
4\end{array}$ & .514 & $\underset{* *}{.338}$ & $\underset{* *}{.480}$ & .521 & $\underset{* *}{.676}$ & 1 & & & & & & \\
\hline $\begin{array}{l}\text { Child Care } \\
\text { Provision }\end{array}$ & 2.01 & $\begin{array}{l}1.29 \\
1\end{array}$ & .739 & .586 & .579 & .582 & .777 & .619 & 1 & & & & & \\
\hline $\begin{array}{l}\text { Social } \\
\text { family } \\
\text { Events }\end{array}$ & 2.44 & .935 & .422 & $\underset{* *}{.462}$ & $\underset{* *}{.531}$ & $\underset{* *}{.541}$ & $\underset{* *}{.573}$ & .469 & $\underset{* *}{.590}$ & 1 & & & & \\
\hline $\begin{array}{l}\text { Flexible } \\
\text { working } \\
\text { Environmen } \\
\text { t }\end{array}$ & 1.96 & $\begin{array}{l}1.27 \\
9\end{array}$ & .459 & .172 & $\underset{* *}{.575}$ & .487 & $\underset{* *}{.475}$ &.$_{* *}^{.572}$ & ${ }_{* *}^{.386}$ & $\underset{* *}{.412}$ & 1 & & & \\
\hline $\begin{array}{l}\text { Impact of } \\
\text { WLB on } \\
\text { Turnover }\end{array}$ & 1.75 & .978 & .496 & $\underset{* *}{.381}$ & $\underset{* *}{.525}$ & $\begin{array}{l}.604 \\
* *\end{array}$ & ${ }_{* *}^{.643}$ & .561 & ${ }_{* *}^{.618}$ & $\underset{* *}{.706}$ & ${ }_{* *}^{.606}$ & 1 & & \\
\hline $\begin{array}{ll}\text { Impact } & \text { of } \\
\text { WLB } & \text { on }\end{array}$ & & & & & & & & & & & & & & \\
\hline $\begin{array}{l}\text { Employee } \\
\text { Loyalty \& } \\
\text { Commitmen } \\
\text { t }\end{array}$ & 1.65 & .914 & .359 & .417 & .525 & .609 & $\underset{* *}{.532}$ & .470 & ${ }_{* *}^{.482}$ & ${ }_{* *}^{.654}$ & .532 & .80 & 1 & \\
\hline $\begin{array}{l}\text { Impact on } \\
\text { Retention }\end{array}$ & 1.54 & .744 & $\underset{* *}{.515}$ & .294 & $\underset{* *}{.533}$ & $\underset{* *}{4 * 64}$ & $\underset{* *}{.574}$ & $\underset{* *}{.572}$ & .667 & .395 & .384 & $\begin{array}{l}.54 \\
8^{* *}\end{array}$ & $\underset{* *}{.370}$ & 1 \\
\hline
\end{tabular}

Note. ${ }^{* *}$. Correlation is significant at the 0.01 level (2-tailed).

The correlation coefficient taking the variables as mentioned in the table above 1, were found to be significant 1 . The Correlation and Coefficient indicates the relatedness of the factors on the basis of all the variables. It says there is a significant positive relation between variables and the factors. Organizational Support Mechanisms were found to be related to the Organizational WLB Policy and Practices with the respective variables and WLB policies are related to employee retention. The highest mean value of 2.26 for supportive management as part of the organizational culture clearly indicates, that it is a crucial factor and it is highly required for the WLB policy planning and implementation which is definitely going to retain the talent.

The findings show that a WLB supportive culture mediates the effect of the availability of WLB practices on organizational performance. There is a significant mediating effect on the relationship between the WLB and employee retention. 


\section{Conclusion}

Life is indeed beautiful. But in today's demanding workplace workers have many competing responsibilities Work-life conflict is a serious problem that impacts workers, their employers and even the communities.

Evidence suggests that improvements in people management practices with a high supportive work culture characterized by work time and work life flexibilities contributes to increased work life balance and make the employees more productive. The role of the corporate culture has a strong role to play between Work Life Balance Practices and the HR issues like recruitment, retention, turnover, commitment, satisfaction and productivity.

\section{Practical Implications}

The study has practical implication for those IT organizations especially who wish to retain the talent. To reduce the rate of turnover and bring high performance, employee satisfaction and excellent organizational outcomes, talent retention through family friendly work life policy is crucial. It is not only going to make the employee happy and productive but also differentiate the organization as an employer of choice. The study encourages organizations to take a proactive role for developing a more supportive and conducive employee friendly culture that can facilitate on the policies implementation.

\section{Scope for Further Research}

The study gives new insights and research directions on work-life balance practices and their relationship to organizational performance and employee productivity. The mediating and moderating effect of culture in bringing job satisfaction, commitment, turnover intention and employee health and stress can be further explored not only in IT industry but in all types of industry.

\section{References}

Baron, J. N., \& Hannan, M. T. (2002). Organizational blue prints for success in high-tech startups. California Mangement Review, 44(3), 8-35. http://dx.doi.org/10.2307/41166130

Brockbank, W. (1999). If HR Were Really Strategically Proactive: Present and Future Directions in HR's Contribution to Competitive Advantage. Human Resource Management, 38(4), 337. http://dx.doi.org/10.1002/(SICI)1099-050X(199924)38:4<337::AID-HRM8>3.0.CO;2-5

Corporate Leadership Council. (2004). Driving performance and retention through employee engagement. Retrieved September 23, 2009, from http://www.mckpeople.com.au/SiteMedia/w3svc161/Uploads/Documents/760af4

Estes, S. B., \& Michael, J. (2005). Work-family policies and gender inequality at work: A Sloan Work and Family Encyclopedia entry. Retrieved March 16, 2007, from http://wfnetwork.bc.edu/encyclopedia_entry.php?id=1230\&area=All

Groover, S. L., \& Croocker, K. J. (1995). Who appreciates family-responsive human resource policies, The impact of family-friendly policies on the organizational attachment of parents and non-parents. Personal Psychology, 48, 271-288. http://dx.doi.org/10.1111/j.1744-6570.1995.tb01757.x

Hughes, J., \& Bozionelos, N. (2007). Work-life balance as source of job satisfaction and withdrawal attitudes. Personal Review, 36(1), 145-154. http://dx.doi.org/10.1108/00483480710716768

Ioanlazar, Osoian, C., \& Patriciaratiu. (2010). The Role of Work-Life Balance Practices in order to Improve Organizational Performance. European Research Studies Journal, 13(1), 201-214.

James, A., Breaugh, N., \& Kathleen, F. (2008). Work-Family Conflict: The Importance of Family-Friendly Employment Practices and Family-Supportive Supervisors. Journal of Business and Psychology, 22(4), 345-353. http://dx.doi.org/10.1007/s10869-008-9081-1

Janki, C. (2009). Employee Retension-A Major Concern to Organisations. HRM Review, 9(4), 59-62. The ICFAI University Press.

Kanwar, Y. P. S., Singh, A. K., \& Kodwani. (2009, April-June). Work Life Balance and Burnouts as predictors of Job Satisfaction in the IT - ITEs industry. The Journal of Business Perspective, 13, 2-12. http://dx.doi.org/10.1177/097226290901300201

Kaushik, B. M. (2009, Marth). Exit interviews: Confessions by the Departing Employees. HRM Review, 34-36.

Kopelman, R. E., Prottas, D. J., Thomson, C. A., \& Jahn, E. W. (2006). A multi level examination of work-life practices ,Is more always better? Journal of managerial issues, 18, 232-253. 
Kossek, E. E., \& Ozeki, C. (1998). Work-family conflict, policies and the job-life satisfaction relationship. A review and direction for organizational behavior -human resource research. Journal of Applied Psychology, 83, 139-149. http://dx.doi.org/10.1037/0021-9010.83.2.139

Landauer, J. (1997). Bottom-line Benefits of Work/Life Programmes. HR Focus, 74(7), 3-4.

Lobel, S. A., \& Kossek, E. E. (1996). Human Resource Strategies to support Diversity in Work and Personal lifestyle, Beyond the "family friendly" organization, In Kossek ,E.E and Lobel ,S.A. Ed.,Managing Diversity. Human Resource Strategies for transforming the workplace, 221-243. Blackwell, Cambridge, MA.

Lockwood, N. R. (2003). Work /Life Balance: Challenges and Solutions. SHRM Journal, 48(6), 81-90.

Lourel, M., Ford, M. T., Gamassou, C. E., Guéguen, N., \& Hartmann, A. (2008). Negative and positive spillover between work and home: Relationship to perceived stress and job satisfaction. Journal of Managerial Psychology, 438-449.

Murugan, S. M. (2009). A study on organizational culture and its impact on the performance of IT employees in Chennai. The icfai journal of Management Research, 8(5).

Osterman, P. (1995). Work/family programmes and the employment relationship. Administrative Science Quarterly, 40, 681-700. http://dx.doi.org/10.2307/2393758

Perry-Smith, J. E., \& Blum, T. C. (2000). Work-family human resource bundles and perceived organizational performance. Academy of Management Journal, 43, 1107-1117. http://dx.doi.org/10.2307/1556339

Rajanish, R. (2008). Work Life Balance in IT Sector. Journal of IPM, 9(1), 26-37.

Sheridan, J. E. (1992). Organizational Culture and Employee Retention. Academy of Management Journal, 48(1), 50-68.

Shrotriya, V. (2009). Balancing the See-Saw of Work and Life. HRM Review, 42. ICFAI University Press.

\section{Copyrights}

Copyright for this article is retained by the author(s), with first publication rights granted to the journal.

This is an open-access article distributed under the terms and conditions of the Creative Commons Attribution license (http://creativecommons.org/licenses/by/3.0/). 